\title{
Angus Deaton, The Great Escape: Health, Wealth, and the Origins of Inequality
}

\author{
(Princeton University Press, Princeton, 2013)
}

Reviewed by Michael Palmer ${ }^{1}$

Professor Deaton's qualification for tackling this ambitious subject is acknowledged by his award of the 2015 Nobel Prize in Economics. There is perhaps no better authority to bring together the wide branches of health, wealth and inequality, which he does so masterfully in this book. It bespeaks a writer who says it all as he sees it; and not from the vantage of a Princeton ivory tower, but as someone who has spent a career thinking about how to measure and improve the lot of the world's worst off. In closing its pages, there is the sense that there is not much more left to say. It is the story of some of humanity's great escape from deprivation beside the inevitable remaining gaps in global wellbeing.

This is, overall, an optimistic and uplifting read. The past 250 years have witnessed the most spectacular increase in human wellbeing in history. The economies of China and India, accounting for one-third of the world's population, have seen growth rates that are unparalleled in any country or time in history, supporting recent expansions in global living standards. Life expectancy in most parts of the world has soared on the back of achievements in child mortality (for example, a child born in sub-Saharan Africa today is more likely to live to the age of five than a child born in the UK just a century ago). However, it is a dual story of the 'dance between progress and inequality' where almost a billion people still live in destitution and countless children still die from the same diseases that killed European children in the 17th and 18th centuries.

$1 \quad$ University of Melbourne; michael.palmer@unimelb.edu.au. 
There are many books that tell separate stories of wealth and health inequality but in this book both stories are told at once. Wealth and health, it is argued, are each central parts of the story of human wellbeing. The merit of the book lies not in the telling of each story but in its attempt at weaving health and wealth as a self-reinforcing whole. Gaps in income, both between and within countries, correspond to gaps in health. The intriguing part of the story is the claim that income explains less about health than we would think, which Deaton attributes (p. 97) to advancing knowledge and technology, human capital accumulation, and government capacity and institutional quality across countries:

Turning the germ theory into safe water and sanitation takes time and requires both money and state capacity; these were not always available a century ago, and in many parts of the world they are not available today.

While written by a self-professed economist, The Great Escape explores an impressive collection of writings on the subject, from demography, public health, anthropology and history. The book is written for a general audience in a style that is far from that of his earlier works such as An Analysis of Household Surveys. To ease digestion the core contents of the book are summarised in the first two chapters or 60 pages of the book. For the time-pressed reader it may be tempting to end there but I urge you to continue to the pieces of gold that lie in the details of measurement and the author's first-hand experience and anecdotes, such as in the development of World Bank's one-dollar-a-day poverty line. Thereafter the book is divided into three sections on health, money, and how to help those left behind.

Perhaps the real value of the book lies in the last section and Professor Deaton's roadmap of how to close gaps in global inequality. His views on foreign aid are the most controversial. He provides an overview of the aid-effectiveness literature and concludes that aid's past record shows no evidence of an overall beneficial effect. The view that aid weakens institutions, undermines democracy and imperils long-term prosperity is his personal view. He does not, however, see all aid as bad. In particular, he advocates for health aid directed at saving lives, both via research and public health programs. His overarching philosophy that industrialised countries should let others develop on their own, in their own time (just as the industrialised countries themselves did), is a healthy perspective to keep in mind.

This book also carries value as a teaching resource in health economics, development economics, and public health fields. The book draws extensively and effectively upon the use of survey data and graphs - for example, plotting life expectancy and income across countries and over time. Several of these charts can be sourced, free of charge, from gapminder.com as either static 
graphs or as video, which display dynamic shocks such as the great Chinese famine or the HIV/AIDS epidemic. These powerful teaching tools can be used in conjunction with the detailed discussion material provided in Deaton's book.

It is hard to find fault with a book on the life's work of a Nobel laureate. My biggest disappointment is that too much of the book is devoted to material inequality in the US. Whilst the author makes a compelling case for using the US example (citing the availability of historical data, for example) the book could have benefited from further discussion on the important recent work of Thomas Picketty and others on the question of historical global income inequality. In parts, I found the book a little long-winded, which likely reflects its broad intended audience, while in other parts the views seemed more forceful than substantiated, which is, perhaps, well-licensed in the circumstances.

In the vein of Poor Economics, ${ }^{2}$ this is a popular science book about economic development but also about health, which will surely rise in prominence in the field of economics. Refreshingly, Deaton's rethinking to fight global inequality places less emphasis on randomised controlled trials as the best way to find out what works or does not work. The effectiveness of aid, he argues, is ultimately a question about the economy as a whole. In particular, he places significant importance on the quality of institutions and governance, such as in public health interventions, which perhaps will be the book's legacy to health and development economics. More broadly, the book makes a powerful contribution to economists' evolving understanding on health.

While this is an overwhelmingly positive book, it leaves us with the important message that progress should never be taken for granted. Rising within country inequality, climate and sea levels, ageing populations, unknown infectious diseases, economic and political instabilities all pose serious threats to future human wellbeing. The assumption that future generations will enjoy longer, healthier and richer lives is by no means a given. Deaton himself, however, remains cautiously optimistic as advancing knowledge and the great desire to escape will always be on our side.

This is a must-read for anyone interested in health and/or development, and is recommended for economists with an interest in inequality - which is argued compellingly in this book to be among the greatest challenges of our time.

2 Banerjee, A.V. and Duflo, E. 2011, Poor Economics, Public Affairs: New York. 
This text is taken from Agenda, Volume 23 - Number 1, 2016, edited by William Coleman, published 2016 by ANU Press, The Australian National University, Canberra, Australia. 